\title{
CONSTRUCTION OF ISLAMIC BOARDING SCHOOL IN DEVELOPING MODERATE ISLAM
}

\author{
Siti Yumnah \\ Sekolah Tinggi Agama Islam Pancawahana Bangil, Pasuruan Indonesia \\ sitiyumnah30@gmail.com
}

Accepted: 22-07-2020

\begin{abstract}
Islamic teachings are moderate teachings as set out in the Koran. However, at the level of practice, Islam sometimes becomes radical and sometimes becomes liberal. This is because of the lack of in-depth Islamic knowledge. Therefore, this study examines the construction of Islamic thought, develops moderate Islam. Based on the analysis of literature and field facts, moderate Islam in pesantren is inseparable from the $W$ ali Songo who spread the religion of Islam in the archipelago by (1) maintaining the balance of fiqh reasoning and Sufism, (2) making the theology of Ablussunab a monotheistic approach, (3) maintaining traditions that exist in the community. The pesantren develops (1) values in caring for the understanding of Islamic religious thought, (2) values in caring for the understanding of thought among religious people, (3) values in caring for religious and cultural understanding. These values are always maintained and preserved by pesantren in the process of religious thought, education and preaching.
\end{abstract}

Keyword : Construction, Pesantren, Moderate Islam

\section{Abstrak}

Pendidikan Islam adalah ajaran moderat sebagaimana diatur dalam Al Qur'an. Namun, pada tataran praktik, Islam terkadang menjadi radikal dan terkadang menjadi liberal. Ini karena kurangnya pengetahuan Islam yang mendalam. Oleh karena itu, penelitian ini mengkaji konstruksi pemikiran Islam, mengembangkan Islam moderat. Berdasarkan analisis literatur dan fakta lapangan. Hasil penelitian ini menunjukan Islam moderat di pesantren tidak dapat dipisabkan dari Wali Songo yang menyebarkan agama Islam di kepulauan dengan (1) menjaga keseimbangan penalaran figh dan tasawnf, (2) menjadikan teologi Ablussunah pendekatan monoteistik, (3) mempertabankan tradisi yang ada di masyarakat. Pesantren mengembangkan (1) nilai-nilai dalam merawat pemahaman pemikiran keagamaan Islam, (2) nilai-nilai dalam merawat pemahaman pemikiran di antara umat beragama, (3) nilai-nilai dalam merawat pemahaman agama dan budaya. Nilai-nilai ini selalu dipertahankan dan dilestarikan oleh pesantren dalam proses pemikiran keagamaan, pendidikan dan pemberitaan.

Kata Kunci: Konstruksi, Pesantren, Islam Moderat 


\section{INTRODUCTION}

Pesantren is one of the traditional institutions that are still phylactic in contributing to the pattern of Islam that is Rahmatan lil Alamin, especially idealism keeping the brotherhood of mankind in the nation and state comprising various ethnic, religious, racial, and cultural ${ }^{1}$. This shows that Islam developed in Indonesia has an uncommon pattern than in other Islamic countries, even the world recognizes that Indonesia is a country that is regarded as the home of the moderate Islamic model compared with Islam in some Middle Eastern countries ${ }^{2}$. In caring for the Brotherhood of fellow Muslims, Indonesia has the best record in preserving the brotherhood of Muslims, so that the things that lead to the split of the Brotherhood of Muslims have never occurred in the national Scale ${ }^{3}$.

Islamic Bording School/Pesantren has a successor role of Walisongo (The Guardian Nine in Java) inheritance in institutional peacekeeping in Indonesia from the past, present and future. With the repeal of the formulation of the BILL of Pesantren and religious education became legislation on legislation, a process in the House of Representatives reflects the serious legal attention of the formal role and existence of pesantren in building efficacy in Indonesia. In late 2019 then, it became an awaited momentum considering that the DPR had formed a working committee (Panja) and successfully completed a variety of inventory issues (DIM) list in the BILL. Even in last September in 2019, the DPR has officially validated the LAW of Pondok Pesantren and religious education ${ }^{4}$.

It differs from other Islamic countries. Although it comprises $100 \%$ of Muslims, it has to be fought between one group and another because of different genres. In maintaining fraternity among religious people, the Indonesian people can develop fraternity among religious people so that there is no conflict with the name of certain religions. ${ }^{5}$ Adherence between the religionists respects and appreciates each of their beliefs. Work together in overcoming humanitarian problems. After the tragedy of religious conflict in eastern Indonesia, the conflict never happened again ${ }^{6}$.

\footnotetext{
${ }^{1}$ Bashori Bashori, "Modernisasi Lembaga Pendidikan Pesantren Perspektif Azyumardi Azra," Nadwa 11, no. 2 (November 17, 2017): 269, https://doi.org/10.21580/nw.2017.11.2.1881; Muhammad Anas Maarif et al., "Character Education Through Dhikr Tariqa Qadiriyya Naqhsabandiyya Al-Usmaniyya Indonesia," Hampstead Psychological Associates 24, no. 07 (2020): 9.

2 Hamid Fahmy Zarkasyi, "Appraising the Moderation Indonesian Muslims with Special Reference to Muhammadiyah and Nahdlatul Ulama," Addin 12, no. 1 (2018): 1-30, https://www.neliti.com/publications/272038/appraising-the-moderation-indonesian-muslims-with-specialreference-to-muhammadi.

3 Muhammad Anas Ma`arif and Ibnu Rusydi, "IMPLEMENTASI PENDIDIKAN HOLISTIK DI PONDOK PESANTREN AMANATUL UMMAH MOJOKERTO,” EDUKASI: Jurnal Penelitian Pendidikan Agama Dan Keagamaan 18, no. 1 (April 27, 2020), https://doi.org/10.32729/edukasi.v18i1.598.

${ }^{4}$ Hasbi Indra, "Salafiyah Curriculum at Islamic Boarding School in the Globalization Era," TARBIYA: Journal of Education in Muslim Society 4, no. 1 (June 13, 2017): 74-88, https://doi.org/10.15408/tjems.v4i1.4960.

${ }^{5}$ It can be proven in 5 years ago, that the Indonesian Ulema Council (MUI) has been a campaign that has a moderate Islamic-themed (al-Islam al-Wasthy), to the various parts of the homeland in order to harmonize the life of the nation and state. M. Zainuddin \& Muhammad In'am Esha, Islam Moderate: conception, interpretation, and action, (Malang: UIN Maliki Press, 2020), p. 1

${ }^{6}$ Gatot Krisdiyanto et al., "Sistem Pendidikan Pesantren Dan Tantangan Modernitas," Tarbawi: Jurnal Ilmu Pendidikan 15, no. 1 (June 30, 2019): 11-21, https://doi.org/10.32939/tarbawi.v15i1.337.
} 
This shows that Indonesian Muslims are more mature than Islamic understanding in the world in caring for the Brotherhood of mankind ${ }^{7}$. Besides the success of Pesantren in caring for the Brotherhood of Religion and sustainability, Pesantren can also synergize religion and culture $^{8}$. The development of Islamic religion in Indonesia does not destroy the cultures, even religions and cultures synergize so that the efficacy of Islam in Indonesia has a different pattern in actualizing religious values in social life, so that the religion is strong in the presence of cultures that are maintained and continue to be preserved".

The pattern of Islamic sustainability built by the thought of Pesantren has contributed extraordinarily in the lives of mankind. Muslims are not easily persuaded by various conflicts on behalf of religions. Muslims in Indonesia are also easy to accept positive changes that do not intersect with religious values. Various issues of radicalism that hit the Indonesian people also did not significantly develop to influence the efficacy of Muslims in Indonesia, especially pesantren. The know-how that is imported from outside that threatens the unity and unity of the Republic of Indonesia, is also unacceptable except for a small group who do not understand deeply about the meaning of religion.

The phenomenon above is an extraordinary achievement for the life of Muslims in the world because not all Muslims can do the same in the prey's life and state. Middle Eastern countries such as Palestine, Iraq, Yemen, Egypt, Syria, and Turkey, were Islamic States still experiencing social conflicts that destroyed the social order in those countries ${ }^{10}$. Amidst the chaos and conflict that occurred in the Islamic countries, Indonesia as the largest Islamic in the world play its role as a moderate Islam and able to maintain Islam according to its mission, namely Rabmatan Lil Alamin. Since 2004, Indonesia through the Ministry of Foreign Affairs has been a moderate Islamic as a pattern of Indonesian Islam ${ }^{11}$.

Although Islam Indonesia has become a moderate, tolerant and democratic country, the threat of radicalism remains threatening Muslims. Research results, it causes the phenomenon of radicalism by three factors, namely (1) global development, (2) the dissemination of Wahhabism (3) poverty ${ }^{12}$ Information on the conflicts of Islamic States became a medium for radical groups to churning out the feelings of Muslims in the world to gain support and sympathy for spreading the group's understanding. ${ }^{13}$. The implication is the emergence of various movements in the name of religion to get massive sympathy from

${ }^{7}$ M. Zainuddin and Esha Inam, Islam Moderat: Konsepsi, Interpretasi, Dan Aksi (Malang: UIN Maliki Press, 2020).

8 Chusnul Chotimah, "Strategi Public Relations Pesantren Sidogiri dalam Membangun Citra Lembaga Pendidikan Islam," ISLAMICA: Jurnal Studi Keislaman 7, no. 1 (January 23, 2014): 186-210, https://doi.org/10.15642/islamica.2012.7.1.186-210.

9 Syamsun Ni'am, "Pesantren: The Miniature of Moderate Islam in Indonesia," Indonesian Journal of Islam and Muslim Societies 5, no. 1 (2015): 24.

10 Achmad Asrori, "Contemporary Religious Education Model on the Challenge of Indonesian Multiculturalism," JOURNAL OF INDONESLAN ISLAM 10, no. 2 (December 1, 2016): 261-84, https://doi.org/10.15642/JIIS.2016.10.2.261-284.

11 Ahmad Rizky Mardhatillah Umar, "A Genealogy of Moderate Islam: Governmentality and Discourses of Islam in Indonesia's Foreign Policy," Studia Islamika 23, no. 3 (December 30, 2016): 399-433, https://doi.org/10.15408/sdi.v23i3.3157; Ahmad Asrori, "Radikalisme Di Indonesia: Antara Historisitas Dan Antropisitas," KALAM 9, no. 2 (December 30, 2015): 253-68, https://doi.org/10.24042/klm.v9i2.331.

12 Amritha Venkatraman, "Religious Basis for Islamic Terrorism: The Quran and Its Interpretations," Studies in Conflict \& Terrorism 30, no. 3 (April 1, 2007): 229-48, https://doi.org/10.1080/10576100600781612.

13 Asrori, "Radikalisme Di Indonesia." 
Muslims in the world. Islamic Martial arts, martial arts, the caliphate, the Pancasila of Islam are the slogans of several groups who want to build an unknown power by the name of Islamic religion $^{14}$. On the one hand, the slogans have attracted the sympathy of a minor part of the Muslims, but most refuse to be violent because they threaten the unity and unity of humanity in the nation and country. The case eventually made the Muslims split between the national slogan and the religious slogan. Addressing the situation, pesantren can show its existence as a moderate-understanding group to ${ }^{15}$.

The magnitude of the role of pesantren that can care for fraternity among human beings who have differences of tribe, religion, race and culture is a remarkable concept because it can internalize the values of religion in human life in a way that is prudent and wise so it does not pose social conflicts in different groups. Therefore, this article seeks to analyse the concept of the construction of the Islamic boarding school in developing moderate Islam that has been proven to maintain the diversity and the efficacy of humanity that differ in nation and state.

\section{Geneaology of Pesantren Thought}

Pesantren is the oldest Islamic religious institution in the archipelago that has contributed to build a moderate Islamic, tolerant and response to the development of the Times. It does not separate the moderate pattern of Islamic sustainability from the founding fathers, namely the guardians who come to the archipelago that has the joints that are the blessings of the faith and far from violence. The presence of guardians in the land of Java spread Islam with full harmony ${ }^{16}$. The Society of the people of ordinary people or nobility can accept history records that with tolerance of local traditions and to change it into Islamic teachings and to rely on Islamic principles.

The Islamic transmission $W$ alisongo pioneered, which is a brilliant da'wah that practices that is, Islamic tradition that does not harm local traditions and customs. In addition, Islam run by the Walisongo is easily arrested because of its concrete approaches and blending into people's lives. ${ }^{17}$ Abdurrahman Mas'ud explained that $W$ alisongo is a unique Javanese agent capable of combining spiritual and secular aspects in the broadcast of Islam.

The success of Da'wah $W$ alisongo is not separated from the moderate attitude shown by the Guardians. The Da'wah of the $W$ alisongo is not inviting, but communicating a new culture that plays an old tradition that has developed in the archipelago. This communication pattern becomes an attraction for Javanese people with the existence of the guardians who have the

14 Masdar Hilmy, "Whither Indonesia's Islamic Moderatism? A Reexamination on the Moderate Vision of Muhammadiyah and Nu," Journal of Indonesian Islam 7, no. 1 (June 1, 2013): 24-48, https://doi.org/10.15642/JIIS.2013.7.1.24-48; Toto Suharto, "Indonesianisasi Islam: Penguatan Islam Moderat Dalam Lembaga Pendidikan Islam Di Indonesia,” Al-Tabrir: Jurnal Pemikiran Islam 17, no. 1 (May 24, 2017): 15578, https://doi.org/10.21154/altahrir.v17i1.803.

15 Ilyya Muhsin, Nikmah Rochmawati, and Muhammad Chairul Huda, "Revolution of Islamic Proselytizing Organization: From Islamism to Moderate," QIJIS (Qudus International Journal of Islamic Studies) 7, no. 1 (June 3, 2019): 45, https://doi.org/10.21043/qiijis.v7i1.5076.

16 Zamakhsyari Dhofier, Tradisi pesantren: studi pandangan bidup kyai dan visinya mengenai masa depan Indonesia, Cet. 8 rev (Jakarta: LP3ES, 2011); Van Bruinessen Martin, Kutab Kuning Pesantren dan Tarekat, 1st ed. (Yogyakarta: Gading Publising, 2012).

17 Mas`ud Abdurrahman, From Haramain to Nusantara: An Intellectual Trail of Pesantren Architects (Jakarta: Kencana, 2006), 67. 
concept of social order that is more advanced than the existing social order ${ }^{18}$. History notes that Wali Songo preach preaching Islam is not much through the picketing, but more in deed.

In, its development definitively da'wah is do in Nusantara differs greatly from the model of Da'wah that develops in the Middle East region that is more emphasized on the use of religious attributes that are confrontational ${ }^{19}$. The goal is for all walks of life to attract and follow the object. Thus, the Da'wah propagation in the archipelago by Walisongo is not fully influence by the propagation model spread over the Middle East region, which is more symbolic.

One institution that can spread the law is through the educational institution of Pesantren. By spreading his knowledge in pesantren, Walisongo can attract the sympathy of the local people who want to learn about the religion of Islam, not by violence or radical, but in a way that is moderate and harmonious without eliminating elements of social culture values that are already inherent in the community. But initially the pesantren that stood in the early 19th and 20th centuries often suffered from collisions and social and religious friction, Walisongo could fight against the people and superstitions that developed in society. So to this day, boarding continues to exist in carrying its religious mission that is to uphold the teachings of Tawhid. ${ }^{20}$

In the journey of pesantren grows and develops not naturally, but a lot of pressure and obstacles that confront him. With a consistent are attitude is nothing but to save the life and agility of Da'wah Islamiya in the pesantren that has rooted strong. At the beginning of its establishment, Pesantren never did anarchist or confrontational action to the local community, because it is orientation only to distribute Da'wah and can internalize the values of Islamic religion through the education of Pesantren. Thus, people can know the existence of this pesantren as an institution able to educate, reconcile, and help socio-psychic for those who plunged in it. ${ }^{21}$

\section{Construction of Islamic Thought in Pesantren}

Pesantren is the successor of the $W$ alisongo Regent, who seeks to maintain moderate Islam and can interact with surrounding cultures. The joints that have been implanted by the Walisongo remains the basis of the Islamic religious school. In the modern era, boarding schools not only become Islamic religious development institutions but also become educational institutions and da'wah institutions, even the pesantren seeks to be the central

\footnotetext{
18 Nanang Hasan Susanto, “The Walisongo's Educational Leadership through Modelling and Fulfilment of Human Basic Needs," Jurnal Pendidikan Islam 6, no. 2 (December 27, 2017): 311-30, https://doi.org/10.14421/jpi.2017.62.311-330.

19 Alexander Raymond Arifianto, "Islam Nusantara: NU's Bid to Promote 'Moderate Indonesian Islam,"” 2016, https://dr.ntu.edu.sg/handle/10220/40704.

20 Siti Mahmudah Noorhayati, "Pendidikan Multikultural Di Pesantren (Upaya Membendung Radikalisme Di Indonesia)," Madania: Jurnal Kajian Keislaman 21, no. 1 (December 27, 2017): 67-78, https://doi.org/10.29300/madania.v21i1.212.

21 Muhammad Anas Ma`arif, "Internalisasi Nilai Multikulutural Dalam Mengembangkan Sikap Toleransi ( Studi Di Di Pesantren Mahasiswa Universitas Islam Malang)," Nað̧hruna: Jurnal Pendidikan Islam 2, no. 1 (March 24, 2019), https://doi.org/10.31538/nzh.v2i1.179.
} 
middle economic underworld. Pesantren is not only a center for Da'wah development but also a center for economic development ${ }^{22}$.

Referring to the style of Walisongo in teaching Islam, the Guardians do not remit in spreading the Ajara of Islam in Javanese society. Guardians seek to internalize Islamic values in various ways, both with customs, culture, and beliefs. Sunan Kalijaga with Wayang, ${ }^{23}$ Sunan Ampel with his widow, Sunan Bonang with his musical gamelan, Sunan Derajad with the art of his people, Sunan Giri with his Cublak. Suweng, Sunan Kudus with Maskumambang and mijiwali24 the Guardians develop with various cultures and customs that develop in Javanese society. They internalize Islamic values through the culture, both the value of Tawhid, Fiqh, (jurisprudence) Sufism and so on ${ }^{25}$.

The journey of the Guardians suggests that only moderate Islam can mingle with the local culture. The moderate attitude of the guardians makes them easy to change Islam so that society can accept it. Thus, the thinking of the Guardians, which continue by the Pesantren is (1) maintaining the balance of jurisprudence and the Reason Sufism, (2) making Ablussunah theology as a Tawhid approach, (3) maintain the traditions that exist in society.

The strategy of Da'wah used by Walisongo in delivering his knowledge uses the level of understanding of his partners $\left(a l-M a d^{\prime} u w\right)$. For among the students they applied Fiqh al-Abkam, namely the introduction of Islamic norms strictly and deeply. To the laity used Fiqh al-Da'wah, bending and adjusting their level of education. And the highest level is using Fiqh al-Hikmah, where the teachings of Islam can accept by all circles of good public nobility to the clergy Hindu Buddha. This is in line with the three principles of Islamic law enforcement, namely: blocking difficulties, minimizing burdens, and gradually. ${ }^{26}$

In carrying out his mission, Walisongo conducted various thought approaches, such as the Thinking of Bayani (exhortative), Irfani (gnostic) and Burbani (demonstrative). According to 'Abid al-Jabiri, all three approaches are models of epistemological thinking in Islamic philosophy. I source the Bayani approach in the text of revelation manifested in the sharia. While Irfani is a source to intuition and manifests in the world of Sufism, and its sources Burhani to a ratio of logic as in science and philosophy. Through this approach, $W$ alisongo proved to Islam the Javanese community in a relatively quick time. In carrying out his mission, Walisongo conducted various thought approaches, such as the Thinking of Bayani (exhortative), Irfani (gnostic) and Burbani (demonstrative). According to 'Abid al-Jabiri, all three approaches are models of epistemological thinking in Islamic philosophy. I source the Bayani approach in the text of revelation manifested in the sharia. While Irfani is a source to intuition and

${ }_{22}$ Marzuki Marzuki, Miftahuddin Miftahuddin, and Mukhamad Murdiono, "Multicultural Education in Salaf Pesantren and Prevention of Religious Radicalism in Indonesia," Jurnal Cakrawala Pendidikan 39, no. 1 (February 2, 2020): 12-25, https://doi.org/10.21831/cp.v39i1.22900.

23 Muh Fatkhan, Da'wah Culture Walisongo: Application method of Da'wah Walisongo in the multicultural Era, the journal Application of Religious Sciences, Vol. IV, No. 2 December 2003, p. 124

${ }^{24}$ Nasruddin, critical of the role of scholars ' in the process of Islamic acculturation with local culture, journal Adabiyah, Vol. XV number. 1/2005

25 Elly Malihah et al., Research for Social Justice: Proceedings of the International Seminar on Research for Social Justice (ISRISJ 2018), October 30, 2018, Bandung, Indonesia (Routledge, 2019).

${ }^{26}$ Miftaqurrohman, legality typology Walisongo Da'wah al-Qowaid Perspective Fiqhiyah, Journal of Prosiding International Workshop and training of Islamic Research methodology Nusantara, (Surabaya: PW LTNU Jawa Timur, 2019), p. 85-86 
manifests in the world of Sufism, and its source Burbani to a ratio of logic as in science and philosophy. Through this approach, Walisongo proved to Islam the Javanese community in a relatively quick time. ${ }^{27}$

\section{Principles of Fiqh Reasoning and Sufism}

Related to the Psychosufistic writers made as a framework of thinking in the communication of Da'wah, the authors see that the communication pattern of Da'wab-built $W$ alisongo leads to a psychosufistic approach, namely a psychological view in understanding the teachings of Sufism so it can a framework of thought to determine religious attitudes and behavior that adhere to the values of divinity and Insan The psychosufistic approach will direct the people in being and behave in Islamic life despite the various differences and the degree of changing times ${ }^{28}$.

Boarding school is a traditional mass media for scholars ' in teaching and learning the values, teachings, Islamic norms and the practice of worship. Kiai became the main central Islamic teachings in pesantren in maintaining and developing Islamic understanding ${ }^{29}$. Until now, pesantren is still a center of Islamic Religious Studies oriented towards early Islamic thought, namely the Islamic thought of the 7th century until the 13th century. Such thoughts include Tawbid, Figh, hadith, aqidah, and Sufism and some supporting components such as science tajwid, proposal, and science nahwu. ${ }^{30}$ Pesantren reasoned, the scholars thinking in the centuries is still original because it gained the scholarly connection with the previous generation, namely generation tabi'in, sahabat dan rasulullah saw.

Although Pesantren develops a variety of religious sciences, but the most important thing in equipping students is the deepening of the jurisprudence and Sufism. Not all students will understand all science such as science of interpretation, hadith and other secondary sciences ${ }^{31}$. Fiqh and Sufism is the most developed science and implemented in daily life. The Fiqh study strongly dominates the religious teachings in the Pesantren, because the jurisprudence is closely related to everyday life. After the students understand the science of figh, then the students are taught many books of Sufism, such as the book Ibya Ulumuddin, Irsyadul Ibad, Nasoibul Ibad, and other books of Sufism ${ }^{32}$. With a balance of fiqh and Sufism, the students are not ungodly with the physical sciences, because the

27 Andi Arif Rifa'i, "Religious and Tolerant Attitudes of University Students: A Comparative Study," Walisongo: Jurnal Penelitian Sosial Keagamaan 27, no. 1 (July 30, 2019), https://doi.org/10.21580/ws.27.1.3872.

28 Marzuki, Miftahuddin, and Murdiono, "Multicultural Education in Salaf Pesantren and Prevention of Religious Radicalism in Indonesia."

29 Muhammad Latif Fauzi, "Traditional Islam in Javanese Society: The Roles of Kyai and Pesantren in Preserving Islamic Tradition and Negotiating Modernity," Journal of Indonesian Islam 6, no. 1 (June 1, 2012): 12544, https://doi.org/10.15642/JIIS.2012.6.1.125-144.

30 Igor Cherstich, "Review of Martin Von Bruinessen and Julia Day Howell (Editors), Sufism and the 'Modern' in Islam.: London: I. B. Tauris, 2013, Ix + 367 Pp. ISBN 978178076379 8," Contemporary Islam 9, no. 3 (September 2015): 345-47, https://doi.org/10.1007/s11562-013-0285-4; Ali Mas'ud, “Ortodoksi Sufisme K.H. Shalih Darat," Islamica: Jurnal Studi Keislaman 7, no. 1 (January 21, 2014): 24-43, https://doi.org/10.15642/islamica.2012.7.1.24-43.

31 Muhammad Anas Ma arif and Muhammad Husnur Rofiq, "The Role of Islamic Education Teachers in Improving the Character of Nationalism in Boarding School," EDUKASI: Jurnal Pendidikan Islam 6, no. 1 June 21, 2018): 064-078, https://doi.org/10.5281/edukasi.v6i1.323.

32 Zainal Arifin, "The Authority of Spiritual Leadership at Pesantren Temboro Based on Jamaah Tabligh Ideology," Jurnal Pendidikan Islam 6, no. 2 (December 27, 2017): 265-92, https://doi.org/10.14421/jpi.2017.62.265-292. 
proficiency in jurisprudence can justify all means based on its logic. However, the students will not fall into error because it is too deep in Sufism and ignore his firm. Therefore, AlGhazali explained :

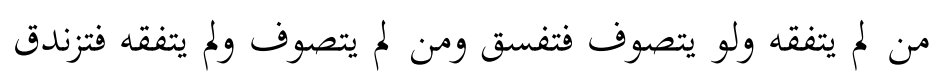

Whoever learns the fiqh, but does not learn Sufism, then he will be ungodly, otherwise whoever learns Sufism and does not learn the jurisprudence will be a pierce.

This is the balance of figh and Sufism that makes the students moderate. The bending of Sufism will mute the rigid fiqh character. Sufism is more Mauri man as a creature of God created to jazz nature and have different potentials. Goodness and evil belong to God. Human does not may justify good. Sufism prioritizes inner potential. Therefore, Muslims will always be well-thought to anyone ${ }^{33}$.

\section{Preserving the theology of Ahlussunnah Wal-Jama'ah}

The theology of Ablussunnah Wal-Jama'ab is an important part in maintaining the moderate attitude of Muslims in Indonesia, especially the students. The theology of Ablussunnab Wal-Jama'ah provides a solid foundation for Muslims to have a balance of religion. Understanding the Ahlussunnah Wal-jama'ah man is difficult to hand and mourn the problem of life as the Jabariyah. Understanding the Ablussunnah Wal-Jama'ah is also difficult to despair when cannot achieve something as a qodariyah or Mu'tazilah. Understanding the Ablussunnah Wal-Jama'ah gives the balance that the man besides trying his very power, but he also must not forget, that the life of mankind is determined by Allah SWT. Human effort in the world is only limited to the Sunnah of life. The outcome, absence of an action, returned to the power ${ }^{34}$.

The Ablussunnab Wal-Jama'ah is apparently penetrated into the soul of the students and become a character in speech, behave and speak. So no wonder, the pesantren has never been troubled and not easily trapped by a group of people who want human damage in the nation and state. Understanding the Ablussunnab Wal-Jama'ah is taught from the lower level. Starting from the book Spsonssosreds Layman, Khoridatul Bahiyyah, until the book Ummul Barahin. These books are always taught and become a students attitude in the life of students in everyday life. Students not only trying to learn hard to get knowledge, but students must do Riyadhoh to get Ridho from Allah SWT. Santri continues to be taught balance in addressing life, so that moderate attitude is completely firmly embedded in his heart.

\section{Caring for Tradition Pesantren}

Pesantren is a religious institution, educational institution, and da'wah institution that has become part of the tradition of the archipelago society. Pesantren has been able to cultivate intellectual rides through educational mechanisms to students. ${ }^{35}$ The expedition

\footnotetext{
33 Abdullah Hadziq, Reconciliation of Sufistic Psychology and Humanistic (Semarang: RaSAIL, 2005), 25.

34 Eka Sugeng Ariadi, "Integrasi Dan Internalisasi Aswaja An Nahdliyah Dalam Penyempurnaan Pola Pikir Kurikulum 2013," Review Pendidikan Islam 2, no. 1 (2015): 22-41.

35 Ahmad Muhakamurrohman, "Pesantren: Santri, Kiai, Dan Tradisi," IBD A: Jurnal Kajian Islam Dan Budaya 12, no. 2 (2014): 118.
} 
education of Pesantren created a unique tradition when compared with religious institutions or educational institutions developed outside the Pesantren. Flexible, dialogical, and open behaviors are a typical way for religious students. It does not mean that the students do not have a firmness in the religion, the inconsistency is part of the dynamic human dynamics. In addition, the concept of maintaining a good old tradition, and taking new things better is a foothold of Islamic sustainability in addressing various matters. Based on that, Islam is truly a religion that carries the mission of Rabmatal Lil'alamin ${ }^{36}$.

This tradition of pesantren that makes students always have a moderate attitude and able to receive the development of the Times easily. Strong principles and moderate attitudes are the most important elements in the lives of Muslims. Based on these principles and attitudes, Muslims are not easily provoke by groups seeking to make Islam a political trasportation. In addition, moderate attitudes are able to save the radical Muslims who contradict the Islamic religious mission itself. Through the tradition of Islamic pesantren in Indonesia becomes one of the most advanced religious people in managing religious social system. The complaints of the students, the relented and forgive, are the characters that are very strong in the students. Thus, the students are not easily interwoven by any agenda to provoke Islam.

Many pesantren traditions can influence the traditions of the surrounding community. In every society there is one that has not lived its religious life in totality, especially in the Islamic law. But after the establishment of Pesantren began people flock to study religious sciences, scavenge fortune, even some who build a house. This means that Pesantren has a distinctive tradition and has influenced the traditions of surrounding communities. ${ }^{37}$

In the study of Cholid Abdullah was find the influence of pesantren on community traditions, such as in terms of dress and behavior of society. People around the pesantren already know how to dress like a student who wear everyday gloves, wearing koko clothes, cap, cleverly playing the instrument hadrah, shake each other, and kiss the hand of Kiai as a solemn sign to him as a student. Originally the local community had a long time to know Islamic traditions before, but they did not want to apply them in their daily life, and can only be applied after it established boarding school in their place. This can be evidence that the tradition of pesantren can contribute to the daily lives of the local people, especially in shaping their personality, which later becomes a treasure of Islamic civilization in Indonesia. ${ }^{38}$

\section{Developing Islamic Moderation Values in Pesantren}

Development of the values of Islamic moderation in pesantren is reflected in the attitude of a polite pesantren in the Act, interact harmoniously in society, promoting a peace and anti-violence and conflict in preaching. The principle implicates the attitude of the students who always appreciate and respect others either in the act or opinion. ${ }^{39}$ This attitude

${ }^{36}$ Hadi Purnomo and Umiarso Umiarso, "Pengelolaan Dan Sistem Pendidikan Islam Berwawasan Rahmatan Lil'alamin: Kajian Atas Gerakan Pendidikan Fethullah Gulen Movement," Cendekia: Jurnal Kependidikan Dan Kemasyarakatan 16, no. 2 (November 22, 2018): 223-44, https://doi.org/10.21154/cendekia.v16i2.1288.

${ }^{37}$ Muhakamurrohman, "Pesantren."

${ }^{38}$ Muhammad Wildan, "Mapping Radical Islam: A Study of the Proliferation of Radical Islam in Solo, Central Java," Contemporary Developments in Indonesian Islam: Explaining the "Conservative Turn 213 (2013).

39 Zainuddin and Inam, Islam Moderat, 61. 
is in line and in harmony with the main mission of Islam, which is the secret of a lil alamin of Islam that brings mercy to all nature. Muhammad as a disclosure of the prophets not only conveyed his guilt to a group of devotees but to all mankind. God Spoke :

It means: "And we do not send thee (Mohammed), but to all the people of man as a bearer of glad tidings, and as a Warner, but most people do not know." QS.

Saba: 28).

The mission of a lil Alamin was required for the pesantren to be moderate so that the mission of Grace came to all mankind. Pesantren as a religious institution, education, and $D a^{\prime} w a h$ has a central role to convey the mission of Rasulullah saw. to mankind. To convey the mission, boarding schools are Hablun Minalloh and Hablun Minannas. As human beings have an obligation to establish connectivity with Allah SWT. In a variety of demonstrations. Nevertheless, man has an obligation to establish relations among humanity. Therefore, Islam does not allow various kinds of destruction, peace, rough attitudes and various forms of peace with the name of Islam.

To maintain a moderate Islam, then pesantren develops moderate Islamic values in the educational process in the pesantren. Moderate Islamic values developed in Pesantren include (1) values in the care of the understanding of the Islamic Mind, (2) values in caring for the understanding among religious believers, (3) values in treating religious and cultural understanding. These values are always maintained and preserved in pesantren in the process of religious thinking, education and $D a^{\prime} w a h$.

\section{Caring for the thought of Islam}

The dynamics of Islamic thought occurred among Muslims when early Islamic beginnings had occurred. How the Siffin War event was a battle between Ali RA troops. With the Muawiyah Army. Addressing this, they teach the students not to justify which one is wrong or which is true. Kiai always conveys that the event was part of their ijithad to uphold the truth ${ }^{40}$. The next generation can not justify the mistake of one, because we are not living in the day. This kind of teaching makes students not easily provoke by sheep. So also in the madzhab. There are four the madzhab that develop to date, namely) the Madhbab Hanafi,) the Madhhab Maliki, Shafi'i) the Madzhab, and Hambali) the Madhhab. The fourth development of this) the Madhhab does not make one group with the other group, but the difference from these four) the Madzhab can make mercy because it can provide a solution for a thing that is not found in the madzhab ${ }^{41}$.

\section{Caring for understanding among religious people}

Kiai is wise in conveying religious understanding, addressing other religions and relations between religious peoples. Although by text, the existence of other religions has diverged, but the language of the Kiai can give an understanding that although their religion is wrong should remain respected ${ }^{42}$. Because it could be religious evangelism today, but at

\footnotetext{
${ }^{40}$ Nazilatus Syukriyah, "Membumikan Al-Quran Dalam Etika Santri Kepada Kyai; Studi Tafsir Q.S Al Kahfi Ayat 66 - 70," Nazhruna: Jurnal Pendidikan Islam 2, no. 2 (August 11, 2019): 209-24, https://doi.org/10.31538/nzh.v2i2.269.

41 Abdul Malik Karim Amrullah, "Perubahan Dan Perkembangan Model Pesantren," El-Hikmah 0, no. 0 (April 27, 2013), http://ejournal.uin-malang.ac.id/index.php/elhikmah/article/view/2238.

42 Wawan Arwani, "Kiai Pesantren Dan Kontribusinya Dalam Mengembangkan Pluralitas Keberagamaan Dan Toleransi Di Kabupaten Cirebon,” Holistik 15, no. 1 (April 5, 2016), https://doi.org/10.24235/holistik.v15i1.434.
} 
the end of his life can turn into Islam. And vice versa, today Islam and later in the day can be pagan ${ }^{43}$. The uncertainty of human life is the consideration of students in order not to ridicule other religions. It does not separate this from the role of Sufism developed in the pesantren, so it is more moderate in addressing it.

From time to time, Pesantren became one of the most characteristic educational institutions in Indonesia that have contributed in spreading the culture of friendly. Since the beginning of the establishment, Pesantren continues to experience its development and become a moderate and accommodating educational institution of inconsistency that occurs in community. ${ }^{44}$ With the enactment of the concept of tasamuh, Tawassut, Tawazun, and $i^{\prime} t i d a t^{45}$ who rooted strongly in the community of pesantren into concrete evidence, that the pesantren is an institution able to internalize while preserving the values of harmony and anti-radicalism ${ }^{46}$. And is something ambiguous if it has regarded the pesantren as a radical Islamic ${ }^{47}$. Because Pesantren was born in Indonesia as an educational institution that can preserve the true religious values, instead of being born as a radicalism seed printer. However, the duty of Pesantren is to print the cadres of the people. ${ }^{48}$

Therefore, the existence of pesantren as an agent of change for the community in the global discourse is expected to be a mediation structure (mediating structure) to understand the problems that arise in the community and can bridge the empowerment of society for the realization of ideals together form the civil society. Because of the "friendly" pesantren with the community, on socio-cultural, political, economic, the Institute can also serve as a locomotive and dynamicator in supervising the change ${ }^{49}$.

\section{Integrating religion and culture}

Tradition of the Islamic community, especially those who have developed in the Pesantren, are not separate from the cultural acculturation. The religions are developing in the archipelago. Before including the religions in the archipelago, Kapitayan religion is the most old belief in the archipelago. Hindu-Buda entered the archipelago and coloring the abundance of archipelago society. Hinduism has a similar construction to the religion of Kapitayan, which is that man can establish a relationship with the gods and the spirits of the spirit. Javanese

43 M. Hadi Purnomo, Kiai dan transformasi sosial dinamika kiai dalam masyarakat (Yogyakarta: Absolute Media, 2016), http://digilib.iain-jember.ac.id/314/.

${ }^{44}$ Miftahul Huda, "Toward a New Theology for a Religiously Restless Region: The Accommodation of Local Traditions into Islamic Law in Lombok," Journal of Indonesian Islam 13, no. 1 (June 2, 2019): 50-72-72, https://doi.org/10.15642/JIIS.2019.13.1.50-72.

$45 \mathrm{KH}$ Ahmad Shiddiq mentions the characteristic characteristics of the residents of Nahdlatul Ulama, including at-Tawasuth which means mid. Al-i'tidal means perpendicular, not leaning to the right nor leaning to the left, at-Tawazun means balance, impartial side, not excessive an element or lack of other elements. And atTasamuh means to respect others or to be accepted and harmonious to the conditions faced. Fitrotun Nikmah, implementation of the concept of At-Tawasuth Ahlus-Sunnah Wal Jama'ah in building children's character at the elementary school level (analysis study Khittah Nahdlatul Ulama), journal Tarbawi Vol. 15, No. 1 January-June 2018, p. $82-83$

46 Fitrotun Nikmah, "Implementasi Konsep at Tawasuth Ahlus- Sunnah Wal Jama'ah Dalam Membangun Karakter Anak Di Tingkat Sekolah Dasar (Studi Analisis Khittah Nahdlatul Ulama)," Tarbawi: Jurnal Pendidikan Islam 15, no. 1 (June 30, 2018), https://doi.org/10.34001/tarbawi.v15i1.720.

${ }^{47}$ Mualimul Huda, "Eksistensi Pesantren Dan Deradikalisasi Pendidikan Islam Di Indonesia (Menyemai Spirit Toleransi Dan Pendidikan Islam Multikultural)," accessed July 22, 2020, https://core.ac.uk/reader/230670376.

48 Abdurrahman Wahid, "Dinamisasi Pendidikan Pesantren," n.d.

49 Arifin, "The Authority of Spiritual Leadership at Pesantren Temboro Based on Jamaah Tabligh Ideology." 
people believe that through Tapa brata, man can be a powerful man and unite with his God. The guardians in spreading Islam does not interfere with the religious beliefs of Kapitayan and Hinduism-Buddhism. The Guardians could design the belief by incorporating the true values of Islamic teachings and far away from the seasonality. They support it because the Javanese culture that is a source from the belief of Kapitayan has an elastic character so that indigo ${ }^{50}$.

The guardians are not just to do cultural purification that has been in the community, but also accommodate and develop the culture so that the cultural Islamization that make the Islamic religion. ${ }^{51} \mathrm{We}$ can say it that the guardians makes the community more advanced because it is more accumulable human needs and more humanized. Pancamakara tradition, which became a tradition of Javanese people, always sacrificed life as one of its ritual forms. The Guardians change it by changing the readings and offerings in the ceremony. It replaces human digging with animal meat, while it replaces blood with white water. While they read the spells, replaced with Dhikr to Allah SWT. Until now, it carried the tradition out in Javanese society and changed its name to Tahlilan.

\section{CONCLUSION}

The moderate Islamic construction developed in the current pesantren, is not separate from the role of Guardian Songo that has been to the foundation of the established Islamic foundations and under the mission of Islam rahmatan lil alamin. The style of da'wah Walisongo is brilliant by communicating to the public about things that become the pleasure and needs of society. As for the thinking of the Guardians, which is to continue by pesantren is (1) maintaining the balance of jurisprudence and the reason sufism, (2) make ablussunah theology as an approach to tawbid, (3) maintain the traditions that exist in society. To maintain a moderate Islam that is a relic of the guardians, then pesantren develops the values of moderate Islam in the process of education in the pesantren. The values of moderate Islam developed in pesantren include (1) values in the understanding's care of Islamic heritage, (2) values in the care of understanding among religious believers, (3) values in caring for religious and cultural understanding. These values are always maintain and preserved in pesantren in the process of religious thought, education and da'wah.

50 Agus Sunyoto, Atlas Wali Songo: buku pertama yang mengungkap Wali Songo sebagai fakta sejarah (Kerjasama Pustaka IIMaN, Trans Pustaka, dan LTN PBNU, 2016).

51 Nasrudin, "Kritis Terhadap Peranan Ulama Dalam Proses Akulturasi Islam Dan Budaya Lokal," Jurnal Adabiyah 15, no. 1 June 20, 2015): 43-61, http://journal.uinalauddin.ac.id/index.php/adabiyah/article/view/694. 
Siti Yumnah

\section{REFERENCES}

Abdurrahman, Mas`ud. From Haramain to Nusantara: An Intellectual Trail of Pesantren Architects. Jakarta: Kencana, 2006.

Amrullah, Abdul Malik Karim. "Perubahan Dan Perkembangan Model Pesantren." El-Hikmah 0, no. 0 (April 27, 2013). http:/ / ejournal.uin-malang.ac.id/index.php/elhikmah/article/view/2238.

Ariadi, Eka Sugeng. "Integrasi Dan Internalisasi Aswaja An Nahdliyah Dalam Penyempurnaan Pola Pikir Kurikulum 2013.” Review Pendidikan Islam 2, no. 1 (2015): 22-41.

Arifianto, Alexander Raymond. "Islam Nusantara: NU's Bid to Promote 'Moderate Indonesian Islam," 2016. https://dr.ntu.edu.sg/handle/10220/40704.

Arifin, Zainal. "The Authority of Spiritual Leadership at Pesantren Temboro Based on Jamaah Tabligh Ideology." Jurnal Pendidikan Islam 6, no. 2 (December 27, 2017): 265-92. https://doi.org/10.14421/jpi.2017.62.265-292.

Arwani, Wawan. "Kiai Pesantren Dan Kontribusinya Dalam Mengembangkan Pluralitas Keberagamaan Dan Toleransi Di Kabupaten Cirebon.” Holistik 15, no. 1 (April 5, 2016). https://doi.org/10.24235/holistik.v15i1.434.

Asrori, Achmad. "Contemporary Religious Education Model on the Challenge of Indonesian Multiculturalism.” JOURNAL OF INDONESLAN ISLAM 10, no. 2 (December 1, 2016): 261-84. https:/ / doi.org/10.15642/JIIS.2016.10.2.261-284.

Asrori, Ahmad. "Radikalisme Di Indonesia: Antara Historisitas Dan Antropisitas." KALAM 9, no. 2 (December 30, 2015): 253-68. https://doi.org/10.24042/klm.v9i2.331.

Bashori, Bashori. "Modernisasi Lembaga Pendidikan Pesantren Perspektif Azyumardi Azra." Nadwa 11, no. 2 (November 17, 2017): 269. https:// doi.org/10.21580/nw.2017.11.2.1881.

Cherstich, Igor. "Review of Martin Von Bruinessen and Julia Day Howell (Editors), Sufism and the 'Modern' in Islam.: London: I. B. Tauris, 2013, Ix + 367 Pp. ISBN 978178076379 8." Contemporary Islam 9, no. 3 (September 2015): 345-47. https://doi.org/10.1007/s11562-0130285-4.

Chotimah, Chusnul. "Strategi Public Relations Pesantren Sidogiri dalam Membangun Citra Lembaga Pendidikan Islam." ISLAMICA: Jurnal Studi Keislaman 7, no. 1 (January 23, 2014): 186-210. https://doi.org/10.15642/islamica.2012.7.1.186-210.

Dhofier, Zamakhsyari. Tradisi pesantren: studi pandangan hidup kyai dan visinya mengenai masa depan Indonesia. Cet. 8 rev. Jakarta: LP3ES, 2011.

Fauzi, Muhammad Latif. "Traditional Islam in Javanese Society: The Roles of Kyai and Pesantren in Preserving Islamic Tradition and Negotiating Modernity." Journal of Indonesian Islam 6, no. 1 (June 1, 2012): 125-44. https://doi.org/10.15642/JIIS.2012.6.1.125-144.

Hadziq, Abdullah. Reconciliation of Sufistic Psychology and Humanistic. Semarang: RaSAIL, 2005.

Hilmy, Masdar. "Whither Indonesia’s Islamic Moderatism? A Reexamination on the Moderate Vision of Muhammadiyah and Nu." Journal of Indonesian Islam 7, no. 1 (June 1, 2013): 24-48. https://doi.org/10.15642/JIIS.2013.7.1.24-48.

Huda, Miftahul. "Toward a New Theology for a Religiously Restless Region: The Accommodation of Local Traditions into Islamic Law in Lombok." Journal of Indonesian Islam 13, no. 1 (June 2, 2019): 50-72-72. https://doi.org/10.15642/JIIS.2019.13.1.50-72.

Huda, Mualimul. "Eksistensi Pesantren Dan Deradikalisasi Pendidikan Islam Di Indonesia (Menyemai Spirit Toleransi Dan Pendidikan Islam Multikultural).” Accessed July 22, 2020. https://core.ac.uk/reader/230670376.

Indra, Hasbi. "Salafiyah Curriculum at Islamic Boarding School in the Globalization Era." TARBIYA: Journal of Education in Muslim Society 4, no. 1 (June 13, 2017): 74-88. https://doi.org/10.15408/tjems.v4i1.4960. 
Krisdiyanto, Gatot, Muflikha Muflikha, Elly Elvina Sahara, and Choirul Mahfud. "Sistem Pendidikan Pesantren Dan Tantangan Modernitas." Tarbawi: Jurnal Ilmu Pendidikan 15, no. 1 (June 30, 2019): 11-21. https://doi.org/10.32939/tarbawi.v15i1.337.

Ma`arif, Muhammad Anas. "Internalisasi Nilai Multikulutural Dalam Mengembangkan Sikap Toleransi ( Studi Di Di Pesantren Mahasiswa Universitas Islam Malang).” Nað̌bruna: Jurnal Pendidikan Islam 2, no. 1 (March 24, 2019). https://doi.org/10.31538/nzh.v2i1.179.

Ma`arif, Muhammad Anas, and Muhammad Husnur Rofiq. "The Role of Islamic Education Teachers in Improving the Character of Nationalism in Boarding School." EDUKASI: Jurnal Pendidikan Islam 6, no. 1 (June 21, 2018): 064-078. https://doi.org/10.5281/edukasi.v6i1.323.

Ma`arif, Muhammad Anas, and Ibnu Rusydi. "IMPLEMENTASI PENDIDIKAN HOLISTIK DI PONDOK PESANTREN AMANATUL UMMAH MOJOKERTO.” EDUKASI: Jurnal Penelitian Pendidikan Agama Dan Keagamaan 18, no. 1 (April 27, 2020). https://doi.org/10.32729/edukasi.v18i1.598.

Maarif, Muhammad Anas, Muhammad Mujtaba Mitra Zuana, Siti Maryam Munjiat, Ibnu Rusydi, Ali Miftakhu Rosyad, and Lu'lu'il Maknuun. "Character Education Through Dhikr Tariqa Qadiriyya Naqhsabandiyya Al-Usmaniyya Indonesia." Hampstead Psychological Associates 24, no. 07 (2020): 9.

Malihah, Elly, Tutin Aryanti, Vina Adriany, Hani Yulindrasari, and Alicia Izharuddin. Research for Social Justice: Proceedings of the International Seminar on Research for Social Justice (ISRISJ 2018), October 30, 2018, Bandung, Indonesia. Routledge, 2019.

Martin, Van Bruinessen. Kutab Kuning Pesantren dan Tarekat. 1st ed. Yogyakarta: Gading Publising, 2012. Marzuki, Marzuki, Miftahuddin Miftahuddin, and Mukhamad Murdiono. "Multicultural Education in Salaf Pesantren and Prevention of Religious Radicalism in Indonesia." Jurnal Cakrawala Pendidikan 39, no. 1 (February 2, 2020): 12-25. https://doi.org/10.21831/cp.v39i1.22900.

Mas'ud, Ali. “Ortodoksi Sufisme K.H. Shalih Darat.” Islamica: Jurnal Studi Keislaman 7, no. 1 (January 21, 2014): 24-43. https://doi.org/10.15642/islamica.2012.7.1.24-43.

Muhakamurrohman, Ahmad. "Pesantren: Santri, Kiai, Dan Tradisi." IBDA: Jurnal Kajian Islam Dan Budaya 12, no. 2 (2014): 109-118.

Muhsin, Ilyya, Nikmah Rochmawati, and Muhammad Chairul Huda. "Revolution of Islamic Proselytizing Organization: From Islamism to Moderate." QIJIS (Qudus International Journal of Islamic Studies) 7, no. 1 (June 3, 2019): 45. https://doi.org/10.21043/qiiis.v7i1.5076.

Nasrudin. "Kritis Terhadap Peranan Ulama Dalam Proses Akulturasi Islam Dan Budaya Lokal." Jurnal Adabiyah 15, no. 1 (June 20, 2015): 43-61. http://journal.uinalauddin.ac.id/index.php/adabiyah/article/view/694.

Ni'am, Syamsun. "Pesantren: The Miniature of Moderate Islam in Indonesia." Indonesian Journal of Islam and Muslim Societies 5, no. 1 (2015): 24.

Nikmah, Fitrotun. "Implementasi Konsep at Tawasuth Ahlus- Sunnah Wal Jama'ah Dalam Membangun Karakter Anak Di Tingkat Sekolah Dasar (Studi Analisis Khittah Nahdlatul Ulama)." Tarbawi: Jurnal Pendidikan Islam 15, no. 1 (June 30, 2018). https://doi.org/10.34001/tarbawi.v15i1.720.

Noorhayati, Siti Mahmudah. "Pendidikan Multikultural Di Pesantren (Upaya Membendung Radikalisme Di Indonesia).” Madania: Jurnal Kajian Keislaman 21, no. 1 (December 27, 2017): 67-78. https://doi.org/10.29300/madania.v21i1.212.

Purnomo, Hadi, and Umiarso Umiarso. "Pengelolaan Dan Sistem Pendidikan Islam Berwawasan Rahmatan Lil'alamin: Kajian Atas Gerakan Pendidikan Fethullah Gulen Movement.” Cendekia: Jurnal Kependidikan Dan Kemasyarakatan 16, no. 2 (November 22, 2018): 223-44. https://doi.org/10.21154/cendekia.v16i2.1288. 
Siti Yumnah

Purnomo, M. Hadi. Kiai dan transformasi sosial dinamika kiai dalam masyarakat. Yogyakarta: Absolute Media, 2016. http:// digilib.iain-jember.ac.id/314/.

Rifa'i, Andi Arif. "Religious and Tolerant Attitudes of University Students: A Comparative Study." Walisongo: Jurnal Penelitian Sosial Keagamaan 27, no. 1 (July 30, 2019). https://doi.org/10.21580/ws.27.1.3872.

Suharto, Toto. "Indonesianisasi Islam: Penguatan Islam Moderat Dalam Lembaga Pendidikan Islam Di Indonesia." Al-Tahrir: Jurnal Pemikiran Islam 17, no. 1 (May 24, 2017): 155-78. https://doi.org/10.21154/altahrir.v17i1.803.

Sunyoto, Agus. Atlas Wali Songo: buku pertama yang mengungkap Wali Songo sebagai fakta sejarah. Kerjasama Pustaka IIMaN, Trans Pustaka, dan LTN PBNU, 2016.

Susanto, Nanang Hasan. “The Walisongo's Educational Leadership through Modelling and Fulfilment of Human Basic Needs." Jurnal Pendidikan Islam 6, no. 2 (December 27, 2017): 311-30. https://doi.org/10.14421/jpi.2017.62.311-330.

Syukriyah, Nazilatus. "Membumikan Al-Quran Dalam Etika Santri Kepada Kyai; Studi Tafsir Q.S Al Kahfi Ayat 66 - 70.” Nazhruna: Jurnal Pendidikan Islam 2, no. 2 (August 11, 2019): 209-24. https://doi.org/10.31538/nzh.v2i2.269.

Umar, Ahmad Rizky Mardhatillah. "A Genealogy of Moderate Islam: Governmentality and Discourses of Islam in Indonesia’s Foreign Policy.” Studia Islamika 23, no. 3 (December 30, 2016): 399_ 433. https://doi.org/10.15408/sdi.v23i3.3157.

Venkatraman, Amritha. "Religious Basis for Islamic Terrorism: The Quran and Its Interpretations." Studies in Conflict \& Terrorism 30, no. 3 (April 1, 2007): 229-48. https://doi.org/10.1080/10576100600781612.

Wahid, Abdurrahman. "Dinamisasi Pendidikan Pesantren,” n.d.

Wildan, Muhammad. "Mapping Radical Islam: A Study of the Proliferation of Radical Islam in Solo, Central Java." Contemporary Developments in Indonesian Islam: Explaining the "Conservative Turn 213 (2013).

Zainuddin, M., and Esha Inam. Islam Moderat: Konsepsi, Interpretasi, Dan Aksi. Malang: UIN Maliki Press, 2020 .

Zarkasyi, Hamid Fahmy. "Appraising the Moderation Indonesian Muslims with Special Reference to Muhammadiyah and Nahdlatul Ulama." Addin 12, no. 1 (2018): 1-30. https://www.neliti.com/publications/272038/appraising-the-moderation-indonesianmuslims-with-special-reference-to-muhammadi. 